\title{
APPLICATION OF SERVQUAL TO IMPROVE LEVEL OF INDUSTRIAL SERVICE IN SOUTH MERUYA WEST JAKARTA
}

\author{
Lien Herliani Kusumah, Sawarni Hasibuan, Hasbullah \\ Universitas Mercu Buana Jakarta, Indonesia.
}

\begin{abstract}
This activity has the purpose to give understanding and to train the ability in service industry in applying the method of service quality to improve the quality of service. Participants in this activity are stakeholders in service industry in the region of South Meruya West Jakarta those are business enterpreneur hosewives who are joined in RPTRA Mahkota South Meruya SelatanWest Jakarta. Method of training in increasing the quality of service is by using the method service quality in service industry they are: delivering material about service quality, delivering material about evaluating customer's satisfaction with the material service quality. Participation and seriousness of the participants can be said is good enough. Result of this training is that members of Mahkota South Meruya feel satisfied and get practical knowledge about application of ServQual.
\end{abstract}

Keywords: Service Quality, Customer's Satisfaction, Service Industry.

\section{INTRODUCTION}

Small and Medium Enterprises (SMEs) in Indonesia still have some weaknesses to be corrected in increasing competitiveness nationally as well as internationally. Classical problems from some reviews, researches and national discussions still range in financial problem, marketing difficulty, raw material supply, low skill of human resource (worker and manager), limited technology, difficulty in booking administration, unstandardized job description, low management quality, low management skill, limited human resource, and low quality of service. Most of SMEs do not have financial report, low aspect of legality, and low quality of technology. If we take conclusion from all the existing problems is the problem of human resource and low service quality. But of course, it doesn't mean that other problems are less important.

Besides human resource, service quality is a demand that must be done by a company in order to survive and get the customer's trust. Customer's consumption pattern and lifestyle demand the company to be able to give qualified service. Success of the company in giving qualified service can be determined by the approach of service quality developed by Parasuraman and Zeithaml (Lupiyoadi, 2006).

Service is interactional process between customers and service provider. So service quality can be defined as the effort to fulfill the need and desire of consumers, and also the accuracy in balancing customer's expectation (Tjiptono, 2007). According to Tjiptono (2007) service quality is level of excellence expectation by the customers and the control of excellence level to fulfill the customers' expectation.

According to Richard Oliver (Barnes, 2003) satisfaction is customer's respond for the fulfillment of the need. It means that evaluation is a form of specification of a product/service or the product/service itself gives level of comfort related to fulfilling a need, including fulfilling the need below expectation or fulfilling the need over expectation of customer. While according to Kotler (1996), customer's satisfaction is the level of someone's feeling after comparing the performance of a product or service which he/she feels according to the expectation. So satisfaction level according Mizenur (2011) is the function of comparison between perceived performance with expected performance. Therefore, evaluation or improvement of service quality becomes very important to do by service industries if they want to always exist in the eye of the customers.

Servqual method is a questionaire used to measure the quality of a service. This method was developed in 1980s by Zeithaml, Parasuraman \& Berry, and has been used in measuring a variety of service (Suparman, 2008). With the questionnaire, we can know how big is the gap exist between customer's perception and customers expectation toward a service company. Questionnaire of Servqual can also be adapted depends on which industry uses the questionnaire. 
Problems concerning the issues about service are numerous and varied enough. Some situations often happen are: issue about poor service; issue about quality of bad and insufficient infrastructure and facilities; issue about unfriendly and disrespectful employees and also not understanding the job; and issue about not responding to customer's complaint and other issues.

This activity has the purpose to give understanding and to give skills in service industry in applying the method of service quality to increase the quality of service.

\section{METHOD}

The public targeted in this community dedication is service industries in the region of South Meruya. The training was conducted in May 2019.

\section{Participants}

Participants of this activity are stakeholders of service industry in the region of South Meruya West Jakarta those are housewives joined in RPTRA Mahkota South Meruya West Jakarta.

\section{Approach}

Method of training in increasing service quality with the method of service quality in service industry are:

1) Delivering material of service quality.

2) Delivering material of evaluating customers' satisfaction with the material of service quality.

Conducting this activity is education and training so it is expected that the participants can give better service in doing their business.

The training used 3 approaches in delivering the materials those are:

1) Lecturing

2) Focus Group Discussion (FGD)

3) Evaluation

Materials of the training is about Application of Service Quality.

\section{RESULT AND DISCUSSION}

\section{Result}

Result of this community dedication is described in three aspects, those are participants' attendance, participation and seriousness of participants.

1. Partipants 'attendance

Participants of this activity are stakeholders of service industry in the region of South Meruya West Jakarta those are business owner housewives joined in RPTRA Mahkota South Meruya West Jakarta. In conducting the activity the number of attended participants are 29 people in one day session.

2. Partipation and seriousness of participants.

It can be said that participation and seriousness of participants are good. This was seen from seriousness of participants in following the activities of delivering material, participation of opinion, as well as question answer.

Participants are invited to participate actively to communicate their opinions on the implementation of Service Quality in its business activities. Some of the participants ' opinions are:

1. The products and services provided shall be in accordance with what is conveyed in Promotion.

2. Listen and receive voice of the customer.

3. Know and can explain the things about the products and services.

4. Prioritize customer satisfaction.

5. Provide the best service to customers.

6. Friendly when providing services to customers

7. Establish good communication with customers.

8. Maintain product quality.

9. Complete the product information on its packaging.

10. Product packaging is attractive and safe.

11. Provides a storefront to place and simultaneously showcase products.

12. Maintain the cleanliness of the area/place of service.

13. Set the layout of the space and the product well.

14. Provide complete and clear information about its products and services. 

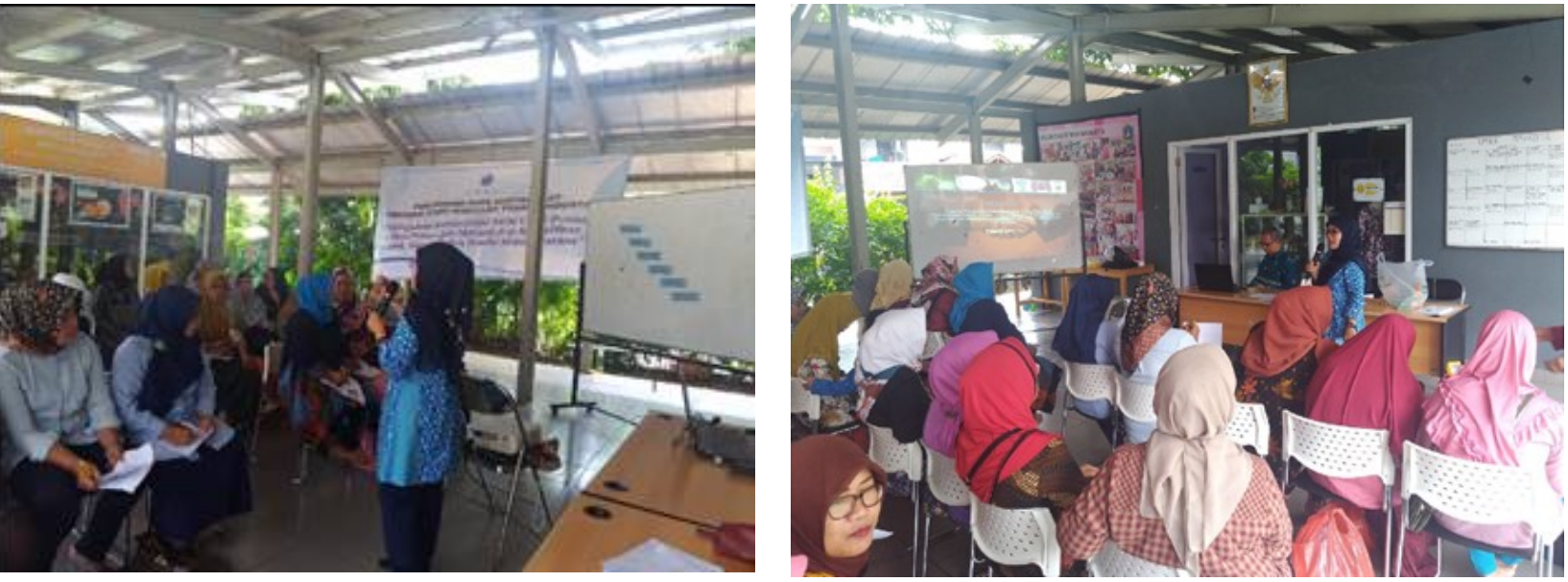

Figure 1 Participants enthusiastically attended Servqual training

\section{Discussion}

Conducting this activity is education and training so it is expected that the participants can give primary service or the best service in doing business activity in RPTRA Mahkota. Customer's satisfaction is the main purpose of better service.

Customers' expectation toward better service are:

- $\quad$ better

- faster

- newer

- cheaper

- simpler

According to Parasuraman et al. (1985) there are 5 qualification for the existence of better quality they are reliability, responsiveness, assurance, attention, and direct proof (tangible).

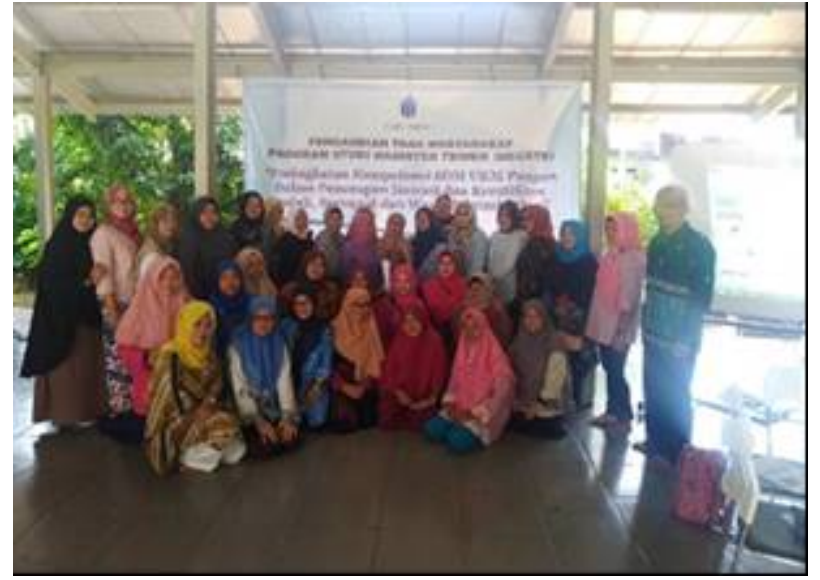

Figure 2 Photograph with a servqual trainee at the end of the event

Results of the training evaluation are as follows:

1. This material has not been got by me ( $87 \%$ participants answer agree)

2. The material delivered is very useful for me bagi saya (100\% participants answer agree)

3. The message of this metarial is very clear and understandable (100\%participans answer agree)

4. Delivering the material is very interesting and not boring (100\% participants answer agree).

5. The time available to deliver the material is enough (100\% participants answer agree). 


\section{CONCLUSION AND SUGGESTION}

\section{Conclusion}

The activity of this community dedication in the form of Sosialitation and and Training Application of Servqual to Improve the Level of Service Industry in South Meruya has been conducted. Result of this training is that the members feel satisfied and and get practical knowlege about application of service quality.

\section{Suggestion}

The activity of training application Servqual to improve the level of service industry in South Meruya is better given to other service because it is very relevant and very useful.

\section{REFERENCES}

Soong, T.T. and Dargush, G.F. (1997). Passive energy dissipation systems in structural engineering. John Wiley \& Sons, Chichester, England.

Handayani, A.W. (2015). Analisis Kepuasan Pelanggan Untuk Meningkatkan Kualitas Pelayanan Admisi dan Promosi Universitas Bakrie. Operations Excellence, 7(1), 16-32.

Herwanto, D., Ikatrinasari, Z.F., and Yuliani, E.N.S. (2013). Integration of Service Quality and Importance Performance Analysis Method in Improving Service Quality at SMK Plus Laboratorium Indonesia, Karawang. International Journal of Engineering, 2(3), 2305-8269.

Ivanauskienė, N. and Justina, V. (2014). Relations between Service Quality and Customer Loyalty: An Empirical Investigation of Retail Chain Stores in Emerging Markets. American International Journal of Social Science, 3(2), 113-120.

Kotler, P. (2002). Manajemen Pemasaran. Edisi Kesepuluh. PT. Indeks, Jakarta.

Ford, L. (2003). How to Provide Gold Standard Customer Service. The Bullet Proof Manager Series. Crestcom Trainer to the World.

Parasuraman, A., Zeithaml, V., dan Berry, L. (2002). SERVQUAL: a multiple-item scale for measuring consumer perceptions of service quality. Retailing: critical concepts, 64(1), 140.

Rahaman, M. M., Abdullah, M., dan Rahman, A. (2011). Measuring service quality using SERVQUAL model: A study on PCBs (Private Commercial Banks) in Bangladesh. Business Management Dynamics, 1(1), 0111 .

Russell, Roberta S. dan Taylor, Bernard W. (2011). Operations Management 7th Edition :Creating Value Along Supply Chain. John Willey and Sons Inc.

Tjiptono, F. and Gregorius, C. (2011). Service Quality an d Satisfaction. Yogyakarta: Andi. 